\title{
Comparative Study of Nutritional Value of Wheat, Maize, Sorghum, Millet, and Fonio: Some Cereals Commonly Consumed in Côte d'Ivoire
}

\author{
Robet Emilie Jocelyne, \\ Konan Béhiblo, \\ Amoikon Kouakou Ernest, \\ Laboratory of Nutrition and Pharmacology, Felix Houphouet Boigny \\ University, Abidjan, Côte d'Ivoire
}

Doi:10.19044/esj.2020.v16n21p118 URL:http://dx.doi.org/10.19044/esj.2020.v16n21p118

\begin{abstract}
This paper focuses on providing a useful database for the decisionmakers for adequate food security policy. It involves making a comparative study of the nutritional values of wheat, maize, sorghum, millet and fonio, which are the five cereals largely consumed in Côte d'Ivoire. In conducting this study, physicochemical analysis were performed. The results reveal that wheat, maize, sorghum, millet, and fonio have an acidic $\mathrm{pH}$. These cereals contain relatively little amount of water and a large proportion of fibers. Carbohydrates represent the highest proportion of the dry matter of the cereals, while maize contains the most important rate. Maize, sorghum, and millet contain more lipids. Wheat, maize, and millet have lower ashes. Wheat and millet contain more proteins. Millet, sorghum, and fonio are the richest cereals in iron. Wheat is rich in calcium but has a lower content of potassium, phosphorus, and Magnesium. Fonio is rich in zinc. Cereals are rich in phytochemical compounds such as phenolic acid, flavonoids, and tannins. It is also important to take into cognizance the presence of antinutritional compounds such as phytates and oxalates. The results show that all the cereals studied represent potential sources of energy in Ivorians food but also has significant sources of fibers and minerals.
\end{abstract}

Keywords: Cereals, Nutritional Value, Energy, Antinutritional Compounds, Côte d'Ivoire

\section{Introduction}

Cereals include plants from the family of Poaceae and are grown especially for their grains. They are often ground into refined flour with more or less whole, but also as whole grains (Ballogou, 2012; Chaib et al., 2015; 
Barkiyou, 2017). For centuries, cereals have represented the basic food in the tropical and semi-arid areas of Africa and Asia (Echendu, 2009; Defan et al., 2015). Their energy contribution in the food intake of West African Sahelian countries represents $63 \%$ on average. In Côte d'Ivoire, they contribute to about $32.6 \%$ of the energy intake per inhabitant and per day. This makes cereals one of the main energy sources and nutrients for populations (ReSAKSS, 2011). The increase in cereal consumption is also attributable to the increase in the consumption of rice. This has led to the detriment of other cereals such as maize, wheat, sorghum, millet, and fonio (ReSAKSS, 2011). Furthermore, the calorific contribution of rice in the daily food consumption of cereals is $19 \%$ on average from 2004 to 2008, which is against $6.4 \%$ and $5 \%$ from corn and wheat respectively (ReSAKSS, 2011). As for millet, sorghum, and fonio, they are not part of the food habits of most people from Côte d'Ivoire. However, those cereals, which are less popular, are rich in nutrients and could positively contribute to the improvement of health and living standards. Therefore, this study could be a useful database for decisionmakers in adequate food security policy. Also, it focuses on comparing the nutritional values of wheat, maize, sorghum, millet, and fonio.

\section{Materials and Methods \\ Food Material}

Whole and dry grains of white maize (Zea mayze), white sorghum (Sorghum bicolor), grey millet (Pennisetum glaucum), white fonio (Digitaria exilis), and tender wheat (Triticum aestivum) were used. These grains were bought in the big market of Korhogo. This city, in the north of Côte d'Ivoire, is known as the largest supply and production center of cereals in Côte d'Ivoire. Whole grains of wheat were also offered by the Grand Moulin d'Abidjan (The Flour Factory of Abidjan), a private cereals distributor located in Abidjan, in the south of Côte d'Ivoire. Whole and dry cereals grains were separated, sieved and washed with distilled water, then dried with an oven (MMM Medcenter Gmbh, D-82152, Germany) at a temperature of $60{ }^{\circ} \mathrm{C}$ for 48 hours. After that, it was turned into flour by means of a mechanic crusher (Rutsch GM 300, Germany). The subsequent flours were sieved with a sieve of $500 \mu \mathrm{m}$ as diameter.+

\section{Methods for Assaying Cereal flours}

\section{a) pH Determination}

The determination of the $\mathrm{pH}$ was carried out with the principle of the AOAC (1990), based on the potentiometric method, using the electrode of the $\mathrm{pH}$ counter (WT pH 302). The assaying helped to determine the total concentration of natural acid of the product. 


\section{b) Determination of Titratable Acidity}

The titratable acidity was determined by means of the method proposed by the AOAC (1990). The titratable acidity was measured with a standard solution of sodium hydroxide $(\mathrm{NaOH})$ in the presence of phenolphtalein which served as a colored indicator.

\section{c) Moisture Content}

The moisture content was determined by using a standard procedure of the AOAC (1990). The principle is based on the mass loss of the sample till it reaches a constant mass at $105^{\circ} \mathrm{C}$.

\section{d) Proteins Content}

Crude proteins are determined from the assaying of total nitrogen by using the method of Kjeldhal (AOAC, 1990). The nitrogen of the dry matter is dosed according to the Kjeldhal's method after the sulphuric mineralisation in the presence of selenium, which is used as a catalyst. The nitrogen content was multiplied by the conversion coefficient of nitrogen into proteins. However, this conversion coefficient varies depending on cereals. More especially, the coefficient is 6.25 for sorghum and fonio, 5.83 for wheat and millet, and 5.6 for maize (FAO, 1998).

\section{e) Lipids Content}

The lipids content was determined by means of the method of AFNOR (1986) using the Soxhlet as extractor. The extraction of oils is obtained by the hexane with Soxhlet type extractor (Unit Tecator, System, HT2, 1045, Sweden). This was done after the evaporation of the solvent and the drying of the capsule in the oven, at a temperature of $105^{\circ} \mathrm{C}$ for $30 \mathrm{~min}$. The difference in weight provides lipid content of the samples.

\section{f) Digestible Carbohydrates Content}

The digestible carbohydrates content is determined by calculation (FAO, 1998). The sugars content is determined following the method with sulfuric phenolic as described by Dubois et al. (1956). The starch content is determined by using the formula recommended by FAO (1947): Starchy content $=0.9(\%$ total carbohydrate $-\%$ total sugars $)$.

\section{g) Fibers Content}

The fibers content is determined by using the Van Soest's method (1963). The method used to determine the ash is the one described by AOAC (1990), which consists of burning a sample till white ashes is gotten. The cap containing the sample is put in a muffle furnace (PYROLABO) and submitted 
at a temperature of $550{ }^{\circ} \mathrm{C}$ for five hours. Then the cap is taken out of the muffle furnace and kept cooled in a dryer. Thereafter, it is weighed.

\section{h) Energy Value}

The energy value of the sample is calculated with specific coefficient of Atwater (1899) for the proteins, the lipids, and the carbohydrate.

\section{i) Minerals Contents}

Calcium, copper, iron, potassium, magnesium manganese, sodium, phosphor, and zinc have been measured out in the ash with electronic scanning. This is coupled with an energy-dispersive spectroscopy (MEB/EDS), which is an electronic scanning Microscope/energy-dispersivespectroscopy.

\section{j) Polyphenols Contents}

The polyphenols are determined based on the method of Singleton et al. (1999) using Folin-Ciocalteu's reactant on the methanolic extract. The optic density is read with a spectrophotometer (PG INSTRUMENT) at 725 nm against a blank.

\section{k) Flavonoids Contents}

The content in flavonoids is determined with the method of Meda et al. (2005), on the methanolic extracts, using the aluminum trichloride and sodium acetate as reactant. The absorbance is read with a spectrophotometer (PG INSTRUMENT) at $415 \mathrm{~nm}$ against a blank.

\section{I) Tannins Contents}

The assaying of tannins was carried out based on the method described by Bainbridge et al. (1996), and vanilin was used as reactant on the methonolic extracts. The absorbance is read with a spectrophotometer (PG INSTRUMENT) at $500 \mathrm{~nm}$ against a blank.

\section{m) Phytates Contents}

Phytates are quantified based on the methods described by Latta and Eskin (1980) under magnetic agitation which is associated with the reactant of Wade. The absorbance is read with a spectrophotometer (PG INSTRUMENT) at $490 \mathrm{~nm}$ against a control.

\section{n) Oxalates Contents}

Oxalates are measured out by using the method of Day and Underwood (1986). The sample is homogenised in the soda under magnetic agitation, 
which is a filtered mixture on Wathman paper. It is also titrated immediately with a solution of potassium permaganate.

\section{Statistical Analysis}

The results are reported under the form of average standard deviation. The comparisons of the values of the physico-chemical parameters are carried out with the STATISTICA software, version 6.1. Analysis of variance followed by the Newman Keuls test is carried out. The significance of the differences of average is obtained with a risk error of $\alpha \leq 0.05$.

\section{Results}

\section{Physicochemical Values of Different Cereals}

The study of the physico-chemical composition is assessed by dry matter (DM) (Table 1). The results reveal that all the cereals under study have an acidic $\mathrm{pH}$. The $\mathrm{pH}$ values are between $4.80 \pm 0.01$ for fonio and $6.83 \pm 0.01$ for wheat. Values of titratable acidity (AT) vary from $2.49 \pm 0.0 \mathrm{mEq} / 10 \mathrm{~g}$ $\mathrm{DM}$ (wheat) to $7.25 \pm 0.28 \mathrm{mEq} / 10 \mathrm{~g} \mathrm{DM}$ (fonio). Moisture rate is lower $(10.72 \pm 1.05 \% \mathrm{FM})$ in wheat and higher $(11.72 \pm 0.20 \mathrm{FM})$ in fonio. The results of the analysis also show that protein values are between a rate of 12.24 $\pm 0.94 \% \mathrm{DM}$ for wheat and $7.10 \pm 0.96 \% \mathrm{DM}$ for maize. The lowest content in lipids is obtained with wheat $(1.73 \pm 0.42 \% \mathrm{DM})$ and fonio $(1.62 \pm 1.11 \%$ DM). Maize is richer in carbohydrates $(75.48 \pm 2.89 \% \mathrm{DM})$ and in total sugars $(3.66 \pm 0.66 \% \mathrm{DM})$. The highest rate of starch is obtained with wheat $(68.24$ $\pm 2.16 \% \mathrm{DM})$ and the lowest with sorghum (61. $20 \pm 4.25 \% \mathrm{MS})$. Maize $(6.69 \pm 0.15 \% \mathrm{MS})$ and sorghum $(8.14 \pm 1.07 \% \mathrm{MS})$ have higher values of fibers than those of wheat $(2.81 \pm 0.26 \% \mathrm{MS})$, millet $(3.89 \pm 0.51 \% \mathrm{MS})$, and fonio $(3.38 \pm 1.04 \% \mathrm{MS})$. Fonio has the greater value $(8.22 \pm 0.49 \% \mathrm{DM})$ of ashes and wheat has the lowest $(1.41 \pm 0.57 \% \mathrm{DM})$. The calculated energy value of maize $(321.79 \pm 18.03 \mathrm{Kcal} / 10 \mathrm{~g} \mathrm{DM})$ is higher than that of the other cereals under study.

Table 1. Physicochemical composition of cereals

\begin{tabular}{|c|c|c|c|c|c|}
\hline \multirow{2}{*}{ Parameters } & \multicolumn{5}{|c|}{ Cereals } \\
\hline & Wheat & Maize & Sorghum & Millet & Fonio \\
\hline pH & $6.83 \pm 0.01^{\mathrm{e}}$ & $6.57 \pm 0.01^{\mathrm{c}}$ & $6.63 \pm 0.01^{d}$ & $6.45 \pm 0.01^{b}$ & $4.80 \pm 0.01^{\mathrm{a}}$ \\
\hline TA (mEq / 100 g DM) & $2.49 \pm 0.00^{a}$ & $4.48 \pm 0.00^{\mathrm{c}}$ & $3.97 \pm 0.00^{b}$ & $5.46 \pm 0.00^{d}$ & $7.25 \pm 0.28^{e}$ \\
\hline Moisture (\% FM) & $10.72 \pm 1.05$ a & $11.51 \pm 0.82^{c}$ & $11.57 \pm 0.75^{c}$ & $11.31 \pm 0.42^{b}$ & $11.72 \pm 0.20^{d}$ \\
\hline Proteins (\% DM) & $12.24 \pm 0.94^{\mathrm{d}}$ & $7.10 \pm 0.96^{\mathrm{a}}$ & $8.99 \pm 1.86^{b}$ & $11.09 \pm 0.12^{\mathrm{c}}$ & $8.12 \pm 1.12^{b}$ \\
\hline Lipids (\% DM) & $1,73 \pm 0.42^{b}$ & $4.18 \pm 1.15^{d}$ & $3.65 \pm 0.70^{c}$ & $4.58 \pm 0.43^{\mathrm{e}}$ & $1.62 \pm 1.11^{\mathrm{a}}$ \\
\hline Carbohydrates (\% DM) & $73.91 \pm 3.56^{c}$ & $75.48 \pm 2.89^{d}$ & $71.82 \pm 3.89^{b}$ & $71.82 \pm 3.62^{b}$ & $70.40 \pm 3.95^{a}$ \\
\hline Sugar (\% DM) & $2.91 \pm 0.30^{c}$ & $3.66 \pm 0.66^{\mathrm{e}}$ & $2.56 \pm 0.55^{b}$ & $3.31 \pm 0.75^{\mathrm{d}}$ & $2,01 \pm 0.75^{a}$ \\
\hline Starch (\% DM) & $68.24 \pm 2.16^{\mathrm{d}}$ & $65.69 \pm 5.09^{c}$ & $61.20 \pm 4.25^{\mathrm{a}}$ & $64.80 \pm 3.51^{b}$ & $65.12 \pm 2.65^{c}$ \\
\hline Fibers (\% DM) & $2.81 \pm 0.26^{\mathrm{a}}$ & $6.69 \pm 0.15^{d}$ & $8.14 \pm 1.07^{\mathrm{e}}$ & $3.89 \pm 0.51^{c}$ & $3.38 \pm 1.04^{b}$ \\
\hline
\end{tabular}




\begin{tabular}{l|c|c|c|c|c}
\hline Ashes (\% DM) & $1.41 \pm 0.57^{\mathrm{a}}$ & $1.79 \pm 0.09^{\mathrm{b}}$ & $4.16 \pm 0.58^{\mathrm{d}}$ & $2.16 \pm 0.71^{\mathrm{c}}$ & $8.22 \pm 0.49^{\mathrm{e}}$ \\
\hline EV (Kcal / 100 g DM) & $308.22 \pm 14.36^{\mathrm{b}}$ & $321.79 \pm 18.03^{\mathrm{d}}$ & $308.84 \pm 15.13^{\mathrm{b}}$ & $319.39 \pm 17.67^{\mathrm{c}}$ & $284.72 \pm 19.65^{\mathrm{a}}$ \\
\hline
\end{tabular}

The variance of analysis is followed by Newman-Keul's multiple comparison test on the verge of $5 \%$. On the same line, the averages followed by different letters are significantly different $(\mathrm{p} \leq 0.05)$; TA:

Titratable acidity. EV: Energy value. . DM: Dry Matter. FM: fresh matter. The averages are from three samples per cereal

\section{Minerals Contents in Cereals}

The mineral contents are assessed as $\mathrm{mg}$ for $100 \mathrm{~g}$ of ashes (Table 2). This shows that fonio $(19.60 \pm 1.45 \mathrm{mg} / 100 \mathrm{~g}$ of ashes) and wheat (18.11 $\pm 1.23 \mathrm{mg} / 100 \mathrm{~g}$ of ashes) contain more calcium than the other cereals under study. Millet contains the greatest amount of copper $(1.98 \pm 0.33 \mathrm{mg} / 100 \mathrm{~g}$ of ashes). The iron content in wheat $(2.25 \pm 0.25 \mathrm{mg} / 100 \mathrm{~g}$ of ashes) and maize ( $2.92 \pm 0.06 \mathrm{mg} / 100 \mathrm{~g}$ of ashes) are lower than those found in sorghum (10.05 $\pm 0.45 \mathrm{mg} / 100 \mathrm{~g}$ of ashes), millet (15.29 $\pm 0.01 \mathrm{mg} / 100 \mathrm{~g}$ of ashes), and fonio $(10.00 \pm 0,08 \mathrm{mg} / 100 \mathrm{~g}$ of ashes). The highest potassium contents are found in maize $(276.17 \pm 9.34 \mathrm{mg} / 100 \mathrm{~g}$ of ashes), sorghum (283.80 \pm $34.41 \mathrm{mg} / 100 \mathrm{~g}$ of ashes), millet (283.74 $\pm 28.41 \mathrm{mg} / 100 \mathrm{~g}$ of ashes), and fonio ( $277.08 \pm 22.78 \mathrm{mg} / 100 \mathrm{~g}$ of ashes). On the other hand, wheat (120.75 $\pm 2.66 \mathrm{mg} / 100 \mathrm{~g}$ of ashes) and maize (126.12 $\pm 0.67 \mathrm{mg} / 100 \mathrm{~g}$ of ashes) have the lowest rate of magnesium. Sorghum contains more manganese (3.47 $\pm 2.20 \mathrm{mg} / 100 \mathrm{~g}$ de ashes), sodium (9.04 $\pm 1.26 \mathrm{mg} / 100 \mathrm{~g}$ of ashes), and phosphorus (293.42 $\pm 48.61 \mathrm{mg} / 100 \mathrm{~g}$ of ashes). The lowest rate of zinc is found in maize $(0.83 \pm 0.04 \mathrm{mg} / 100 \mathrm{~g}$ of ashes $)$ and millet $(0.95 \pm 0.08 \mathrm{mg} /$ $100 \mathrm{~g}$ of ashes).

Table 2. Cereal minerals composition

\begin{tabular}{|c|c|c|c|c|c|}
\hline \multirow{2}{*}{$\begin{array}{l}\text { Parameters } \\
\text { (mg / 100 g A) }\end{array}$} & \multicolumn{5}{|c|}{ Cereals } \\
\hline & Wheat & Maize & Sorghum & Millet & Fonio \\
\hline Ca & $18.11 \pm 1.23^{\mathrm{d}}$ & $10.68 \pm 2.12^{c}$ & $9.92 \pm 2.28^{b}$ & $7.57 \pm 1.51^{\mathrm{a}}$ & $19.60 \pm 1.45^{\mathrm{e}}$ \\
\hline $\mathrm{Cu}$ & $0.74 \pm 0.01^{\mathrm{b}}$ & $0.64 \pm 0.08^{a}$ & $0.74 \pm 0.13^{b}$ & $1.98 \pm 0.33^{\mathrm{d}}$ & $0.82 \pm 0.01^{c}$ \\
\hline $\mathbf{F e}$ & $2.25 \pm 0.25^{\mathrm{a}}$ & $2.92 \pm 0.06^{b}$ & $10.05 \pm 0.45^{\mathrm{c}}$ & $15.29 \pm 0.01^{\mathrm{d}}$ & $10.00 \pm 0.08^{c}$ \\
\hline $\mathbf{K}$ & $112.19 \pm 1.91^{\mathrm{a}}$ & $276.17 \pm 9.34^{b}$ & $283.80 \pm 34.41^{\mathrm{c}}$ & $283.74 \pm 28.41^{\mathrm{c}}$ & $277.08 \pm 22.78^{b}$ \\
\hline Mg & $120.75 \pm 2.66^{a}$ & $126.12 \pm 0.67^{b}$ & $179.37 \pm 1.21^{\mathrm{d}}$ & $155.13 \pm 1.59^{c}$ & $156.60 \pm 0.95^{c}$ \\
\hline Mn & $1.86 \pm 0.13^{\mathrm{b}}$ & $1.36 \pm 0.01^{\mathrm{a}}$ & $3.47 \pm 2.20^{\mathrm{d}}$ & $2.65 \pm 0.22^{\mathrm{c}}$ & $1.84 \pm 0.07^{\mathrm{b}}$ \\
\hline $\mathrm{Na}$ & $5.15 \pm 0.01^{\mathrm{d}}$ & $3.74 \pm 0.64^{c}$ & $9.04 \pm 1.26^{\mathrm{e}}$ & $2.04 \pm 1.24^{\mathrm{b}}$ & $1.85 \pm 0.08^{\mathrm{a}}$ \\
\hline $\mathbf{P}$ & $242.80 \pm 0.60^{\mathrm{a}}$ & $284.68 \pm 29.51^{\mathrm{c}}$ & $293.42 \pm 48.61^{\mathrm{e}}$ & $267.08 \pm 62.42^{b}$ & $289.08 \pm 26.07^{d}$ \\
\hline $\mathbf{Z n}$ & $1.23 \pm 0.06^{c}$ & $0.83 \pm 0.04^{\mathrm{a}}$ & $1.40 \pm 0.24^{\mathrm{d}}$ & $0.95 \pm 0.08^{b}$ & $2.27 \pm 0.07^{\mathrm{e}}$ \\
\hline
\end{tabular}

The variance of analysis is followed by Newman-Keul's multiple comparison test on the verge of $5 \%$. On the same line, the averages followed by different letters are significantly different $(\mathrm{p} \leq 0.05)$; A: Ash. 


\section{Phytochemical Contents in Cereals}

Phytochemical screening of phenolic acids, flavonoids, and tannins (expressed in mg per $100 \mathrm{~g}$ of DM) are high for all the cereals under study (Table 3). Maize (173.70 $\pm 3.36 \mathrm{mg} / 100 \mathrm{~g} \mathrm{DM})$ and millet $(173.26 \pm 0.72 \mathrm{mg}$ $/ 100 \mathrm{~g} \mathrm{DM})$ contain more phenolic acids than wheat $(136.59 \pm 0.99 \mathrm{mg} / 100$ $\mathrm{g}$ DM), sorghum (107.25 $\pm 1.13 \mathrm{mg} / 100 \mathrm{~g} \mathrm{DM})$, and fonio $(134.42 \pm 2.81 \mathrm{mg}$ $/ 100 \mathrm{~g} \mathrm{DM})$. Sorghum $(1.51 \pm 0.30)$ contains the lowest amount of flavonoids, while millet has the highest content in tannins $(78.26 \pm 0.35)$.

Table 3. Average content of phytochemical compounds in cereals

\begin{tabular}{l|c|c|c|c|c}
\hline \multirow{2}{*}{$\begin{array}{l}\text { Parameters } \\
(\mathbf{m g} / 100\end{array}$} & \multicolumn{5}{|c}{ Cereals } \\
\cline { 2 - 6 } & Wheat & Maize & Sorghum & Millet & Fonio \\
\hline Phenolic acids & $136.59 \pm 0.99^{\mathrm{b}}$ & $173.70 \pm 3.36^{\mathrm{c}}$ & $107.25 \pm 1.13^{\mathrm{a}}$ & $173.26 \pm 0.72^{\mathrm{c}}$ & $134.42^{ \pm} \pm 2.81^{\mathrm{b}}$ \\
\hline Flavonoids & $4.76 \pm 0.12^{\mathrm{d}}$ & $5.07 \pm 0.15^{\mathrm{e}}$ & $1.51 \pm 0.30^{\mathrm{a}}$ & $2.40 \pm 0.37^{\mathrm{b}}$ & $3.79^{\mathrm{y}} \pm 0.06^{\mathrm{c}}$ \\
\hline Tannins & $23.73 \pm 1.61^{\mathrm{a}}$ & $48.60 \pm 1.66^{\mathrm{c}}$ & $66.68 \pm 1.56^{\mathrm{d}}$ & $78.26 \pm 0.35^{\mathrm{e}}$ & $34.65^{ \pm} \pm 0.43^{\mathrm{b}}$ \\
\hline
\end{tabular}

The variance analysis is followed by Newman-Keul's multiple comparison test on the verge of $5 \%$. On the same line, the averages followed by different letters are significantly different $(\mathrm{p} \leq 0.05)$; DM: dry matter

\section{Antinutritional Contents in Cereals}

The values of antinutrional compounds are expressed in $\mathrm{mg} / 100 \mathrm{~g}$ DM (Table 4). The results show that the content in phytates is higher than the content in millet $(28.14 \pm 0.43 \mathrm{mg} / 100 \mathrm{~g}$ of DM). Meanwhile, sorghum contains more oxalates $(136.67 \pm 2.89 \mathrm{mg} / 100 \mathrm{~g}$ of DM).

Table 4. Average content of antinutritional compounds in cereals

\begin{tabular}{|c|c|c|c|c|c|}
\hline \multirow{2}{*}{$\begin{array}{l}\text { Parameters } \\
(\mathrm{mg} / 100 \mathrm{~g} \text { of } \mathrm{DM})\end{array}$} & \multicolumn{5}{|c|}{ Cereals } \\
\hline & Wheat & Maize & Sorghum & Millet & Fonio \\
\hline Phytates & $12.01 \pm 0.49^{\mathrm{a}}$ & $17.93 \pm 0.21^{\mathrm{c}}$ & $15.99 \pm 0.19^{b}$ & $28.14 \pm 0.43^{\mathrm{e}}$ & $19.48 \pm 0.32^{d}$ \\
\hline Oxalates & $84.99 \pm 0.30^{b}$ & $116.40 \pm 1.05^{\mathrm{c}}$ & $136.67 \pm 2.89^{\mathrm{e}}$ & $130.95 \pm 2.67^{\mathrm{d}}$ & $80.10 \pm 1.43^{a}$ \\
\hline
\end{tabular}

The variance analysis is followed by Newman-Keul's multiple comparison test on the verge of $5 \%$. On the same line, the averages followed by different letters are significantly different $(\mathrm{p} \leq 0.05)$; DM: dry matter

\section{Discussion}

The analysis of the study shows that the $\mathrm{pH}$ of the cereals such as wheat, maize, sorghum, and millet significantly differs from one another and are close to neutrality. The $\mathrm{pH}$ for fonio also largely differs. These values are different from the ones proposed by N'Guessan (2014) for the flour of maize. Additionally, these values offer an indication on the type of microbiota likely to be contaminated of fonio by moisturing. Most of the batteries better develop with $\mathrm{pH}$ close to seven (7). Moreover, moisture develops when the $\mathrm{pH}$ is lower. The increase in moisture implies enzymatic reactions which will influence the titratable acidity (N'Guessan, 2014). This is why the titratable acidity of fonio is high. 
Wheat, maize, sorghum, millet, and fonio contain relatively little amount of water. These contents are lower than those identified by FAO (2012) with white rice. This quality reduces the risk of damage and microbial growth, and thus favours a good conservation of cereals (Echendu et al., 2009). The protein contents of wheat and millet are greater than those of maize, sorghum, and fonio. The values obtained for the proteins are also close to the ones reported by Békoye (2011) on millet. However, these values are inferior to the content reported for millet, sorghum, and fonio by FAO (2012). Nonetheless, they are inferior to the content reported by Padulosi et al. (2009) for sorghum and maize as indicated by Echendu (2009) on fonio. The values obtained for maize, sorghum, and fonio are comparable to that of rice obtained by Saleh et al. (2013). However, this is inferior to the white rice reported by FAO (2012). There are lots of variations in the cereals composition which is related to the genetic factors, environmental factors, and farming practices. In sorghum, the protein content changes according to the place where they are farmed (Jeuffroy \& Oury, 2012). The combination of winter peas and wheat allows an increase in wheat protein content (Pierreux \& Bodson, 2018). In maize, the protein content increases with sandy soils compared to clay and loamy soil (Nyiraneza et al., 2012). In addition, cereals have an unbalanced amino acid composition which is essential with limiting rate, particularly in lysine. Nutrition based on a great consumption of cereals and a low supply of protein must be considered as risky (Smith et al., 2013).

Furthermore, the analysis revealed that among the cereals studied, maize, sorghum, and millet contain more lipids than wheat and fonio. The values obtained for maize, sorghum, and millet are in line with that of FAO (2012) on millet, maize, sorghum, and fonio. These contents can also be compared with those mentioned by Defan (2015) on the variety of maize MDJ, EV8728 and GMRP18 produced in Côte d'Ivoire. The values obtained for fonio are inferior to the content found by Glew et al. (2017). Also, the values obtained for lipids are greater than those indicated by FAO (2012) with white rice. Generally, cereal grains are low in lipids concentrated in the germ and the aleurone (Barkiyou, 2017).

Carbohydrates represent the highest proportion of the dry matter of the cereals under study. Maize contains the most important rate. These values are close to the ones found by Békoyé (2011) for maize. More so, these values are inferior to the content reported by FAO (2012) for the white rice. In fact, cereals essentially consist of carbohydrates. Most come from starch and lower proportions come from total sugars (Defan, 2015). These carbohydrates make up the main source of energy in cereals (Fardet, 2015). This high amount of carbohydrates is in relation with the higher content in starch and in energy, which is noted in this study. The fact that cereals grains contain a relatively high amount of carbohydrates is an advantage which is related to the use of 
their flour for trade products such as starch, glucose, and alcohol (Defan, 2015).

Sorghum and maize have fibers rate superior to those of wheat, millet, and fonio. In addition, all the rates of fibers found in the present study are great and superior to those reported by FAO (2012) with white rice. Such rates were mentioned by FAO (1995), especially with sorghum, due to the presence of bran. Food fibers consist of bioactive compounds which contribute to the prevention of coronary diseases, gastrointestinal tract trouble, and diabetes (Fardet, 2010; Shobana et al., 2010).

Wheat, maize and millet have lower ashes value compared with sorghum and fonio. These values are comparable to those of Defan (2015). The values are also comparable to the ones obtained by Padulosi et al. (2009) which showed that such ash contents, especially for the maize are acceptable. On the other hand, the values obtained for fonio are superior to the ones reported by FAO (2012). A large number of variances in the content of the ashes from cereals grains were reported, especially for pearl millet and sorghum. Genetic and environmental factors play a major role in the determination of this composition (Gamuyao et al., 2012).

The major minerals present in the grains of cereals under study are the sodium, iron, potassium, calcium, phosphorus, and magnesium. The trace elements noted are copper, manganese (Mn), and Zinc ( $\mathrm{Zn})$. These are the minerals found in most of the cereals (Békoyé, 2011; Ikram, 2013). Millet, sorghum, and fonio are the richest cereals in iron $(\mathrm{Fe})$. These results resemble those of Padulosilet al. (2009) and Glew et al. (2015). Wheat is rich in calcium but has a lower content of potassium, phosphorus, and Magnesium. The mineral contents of cereals studied are different from those obtained by Platel et al. (2010). The mineral salts content of the cereals studied are extremely variable and depend on the content in sulphured fertiliser. Therefore, they are influenced by the farming environment (Belaid, 2013). Other factors such as plant population density, season, and hydric constraint also contribute to the variation of the minerals (Gamuyao et al., 2012).

The analysis further revealed that wheat, maize, sorghum, and fonio are rich in phytochemical compounds such as flavonoids and tannins. The values found in this study are higher than the ones reported by Defan et al. (2015) for maize and inferior to the content reported by N'Dri et al. (2012) for sorghum, millet, and fonio after cooking. The presence of phenolic compounds in the grains of cereals prevents losses due to premature germination. Thus, this makes a longer conservation possible (N'Guessan et al., 2014). Besides these considerations, those compounds give cereals some therapeutic properties, especially anti-inflammatory, antibacterial, antioxidant, antithrombotic, heart protection, and vasodilatory (Fardet, 2010; 
Banerjee et al., 2012; Shahidi \& Chandrasekara 2013; Kaddafi et al., 2015; Udeh et al., 2017).

In addition to the phytochemical compounds, this study also revealed the presence of some nutritional inhibitors which are likely to reduce the nutritional value of the cereals. These are the phytates and the oxalates. The values obtained are in harmony with the ones obtained by Ikram et al. (2013). Phytates have a strong binding capacity and can make up insoluble complexes with proteins and some minerals such as iron and zinc. However, they are not available for the body. Nevertheless, the bioavailibilty of proteins and minerals can be improved by some methods of treatment mentioned such as malting, germination, soaking, milling, and cooking (Platel et al., 2010; Udeh et al., 2017). These treatments reduce the quantity of the antinutritional substances present in the cereals and therefore improve the bioavailability of minerals and proteins.

\section{Conclusion}

The analysis of the physiochemical composition revealed that wheat, maize, millet, and sorghum are rich in carbohydrates and energy. They contain a significant quantity of fibers, minerals, low proteins, and lipids content. Their lower quantity of water and the presence of phytochemical compounds provide the capacity to be conserved over a long period of time. However, the presence of nutritional inhibitors affects the nutritional property of the cereals by reducing the bioavailability of proteins and minerals. The high carbohydrate content of these cereals could have the ability to increase post prandial blood glucose. It would therefore be important to analyse this elevation of blood glucose in terms of blood glucose control as part of the prevention of obesity and diabetes.

\section{References:}

1. AFNOR (1986). Recueil de norme française, corps gras, graines oléagineuses, produits dérivés, AFNOR Edition, Paris (France), 527p.

2. Atwater, W. \& Rosa, E. (1899). A new respiratory calorimeter and the conservation of energy in human body, II-Physical, 9: 214-251.

3. AFNOR (1986). Recueil de norme française, corps gras, graines oléagineuses, produits dérivés, AFNOR Edition, Paris (France), 527p.

4. AOAC (1990). Official methods of analysis. Association of Official Analytical Chemists Edition, Washington DC, 684p.

5. Ballogou, V. Y., Sagbo, F. S., Soumanou, M. M., Toukourou, F. \& Hounhouigan, J. D. (2012). Evaluation de la qualité de quelques produits dérivés de deux écotypes de fonio cultivés (Digitaria exilis) au Bénin. Bulletin de la Recherche Agronomique du Bénin, 72: 18407099. 
6. Barkiyou, M. (2017). Contribution à l'étude de l'effet thérapeutique du mil à chandelle «Pennisetum glaucum L.» dans la fragilité osseuse chez le rat wistar. Thèse de doctorat des Sciences de la Vie et de la Santé, Université Mohammed V de Maroc, 123p.

7. Bekoyé, M. B. (2011). Caractérisation chimique et minérale des grains de mil [Pennisetum glaucum (L.) R]. Br. De Côte d'Ivoire. Journal Biologie and Chemistry Sciences, 5 (5) : 2039-2044.

8. Belaid, D. (2013). Zones semi-arides: revisiter la fertilisation phosphate des cereals. Communication au 1er séminaire international, Problématiques agronomiques en régions arides et semi-arides, 28-30 octobre 2013, (SIAZA1) Batna. 6p.

9. Banerjee, S., Sanjay, K.R., Chethan, S. \& Malleshi, N.G. (2012). Finger millet (Eleusine coracana) polyphenols: Investigation of their antioxidant capacity and antimicrobial activity. African Journal of Food Science, 6: 362-374.

10. Chaib, G., Bouchelaleg, A. \& Talbi, R. (2015). Etude phytochimique de quelques varietes de blé tendre (triticum aestivum) et d'orge (hordeum vulgare) et leurs activites biologiques. European Scientific Journal, 11 (30): 1857- 7881.

11. Day, R. A. \& Underwood, A. L. (1986). Quantitative analysis. 5th edition, Prentice, Hall publication, 701p.

12. Defan, K. P., Akanvou, L., Akanvou, R., Nemlin, J. P. \& Kouamé, P. L. (2015). Evaluation morphologique et nutritionnelle des variétés locales de maïs (Zea mays L.) produites en Côte d'Ivoire. Afrique Sciences, 11 (3):181-196.

13. Dubois, M., Gilles, K. A., Hamilton, J. K., Bebers, P. A. \& Smith, F. (1956). Colorimetric method for determination of sugars and related substances. Analysis Chemical. 28: 350-556.

14. Echendu, C.A., Obizoba, I.C., Anyika, J.U. \& Ojimelukwe, P.C. (2009). Changes in Chemical Composition of Treated and Untreated Hungry Rice "Acha” (Digitaria exilis). Pakistan Journal of Nutrition. 8 (11): 1779-1785.

15. FAO (1947). Composition des aliments en principes nutritifs calorifiques, F. A. O., Washington.

16. FAO/OMS (1998). Carbohydrates in Human Nutrition, FAO, Report of an FAO/WHO. Expert Consultation on Carbohydrate, April 14-18 1997. Rome (Italy): FAO. Food and Nutrition p66.

17. FAO (1995). Sorghum and millet in the human nutrition. Food and Nutrition, Rome, 27: 38-188.

18. FAO (2012). West African Food Composition Table. F. A. O., Rome, $148 \mathrm{p}$. 
19. Fardet, A. (2010). New hypotheses for the health-protective mechanisms of whole grain cereals: what beyond fibers. Nutrition Research Review, 23: 65-134.

20. Gamuyao, R., Hyoun Chin, J., Pariasca-Tanaka, J., Pesaresi, P., Catausan, S., Dalid, C., Slamet-Loedin, I., Tecson-Mendoza, E.M., Wissuwa, M. \& Heuer, S. (2012). The protein kinase Pstoll from traditional rice confers tolerance of phosphorus deficiency. Nature, 488: 535-539.

21. Glew, H. R., Laabes, E. P, Presley, J. M., John, S., Ronnee, A., Wang, Y. C., Chang, Y. C. \& Chuang, L. T. (2017). Fatty acid, amino acid, mineral and antioxidant contents of acha (Digitaria exilis) grown on the Jos Plateau, Nigeria. International Journal of Nutrition Metabolic. 5 (1): 1-8.

22. Herum, F. L. (1987). Harvesting and postharvest management. In watson S.A. and Ramstad P.E. Edition Corn. Chemistry and technology, 83-123.

23. Ikram, M. N., Isam, M. A., Suha, O.A., Mohamed, M. E. \& Elfadil, E. B. (2013). Effect of processing methods on antinutritional factors, protein digestibility and minerals extractability of winter sorghum cultivars. Australian Journal of Basic and Applied Sciences, 7 (12): 229-237.

24. Jeuffroy, M. H \& Oury, F. X. (2012). Impact des nouvelles techniques de production, impliquant de faibles niveaux d'intrants, sur la quantité de protéines du blé. Du champ à l'assiète, nouveau enjeu pour la filière blé, 29 mars 2012, France, 23p.

25. Kaddafi, A., Daoudy, K. \& Marmouzi, I. (2015). In vitro antioxidant and anti-inflammatory activities of extracts of pearl millet Pennisetum glaucum L. Jcpr, 7 (6):1-6.

26. Kjeldahl, J. (1973). A new method for the determination of nitrogen in organics substances. Ztschr. Analysis Chemistry, 22: 366p.

27. Meda, A., Lamien, C. F, Ronoto, M., Milogo, J. \& Nacoulma, O. G. (2005). Determination and total phenolic, flavonoïds and proline contents in Burkina Faso Honeys has well as their radical scavenging activity. Food Chemistry, 91: 571-577.

28. Monteiro, P.V., Gopal, D. N., Vrupaksha, T. K. \& Ramachandra, G. (1988). Chemical composition and in vitro protein digestible of Italian millet (Setaria italica). Food Chemistry, 29:19-26.

29. Mouquet-River, C., Icard-Vernière, C., Guyot, P. P., Tou, E. H., Rochette, I. \& Trèche, S. (2008). Consumption pattern, biochemical composition and nutritional value of fermented pearl millet gruels in Burkina Faso. International Journal of Food, Sciences and Nutrition, 59 (7-8):716-729. 
30. N'Dri, Y. D (2012). Potentialités nutritionnelles et antioxydantes de certaines plantes alimentaires spontanées et de quelques légumes et céréales cultivés en Côte D'Ivoire. Thèse de Doctorat des Sciences de la Vie et de la Santé Biologie médicale, pathologie humaine et expérimentale et environnement, università degli studi di parma facoltà di Agraria, 123

31. N'Guessan, Y. D. (2014). Caractérisation physico-chimique, microbiologique et digestibilité enzymatique des farines de céréales vendues sur les marchés d'Abidjan. Thèse de Doctorat d'état èsSciences, Université Nationale de Côte d'Ivoire, 149 p.

32. Nyiraneza, J., Cambouris, A., Ziadi, N., Tremblay, N \& Noulin, M. (2012). Effet de la texture et de la fertilaisation azote sur le rendement et la qualité de blé de printemps. Journée scientifique sur les grandes cultures, 23 Février, Drumondville (QC, Canada), 7p.

33. Padulosi, S., Mal, B., Bala Ravi, S., Gowda, J., Gowda, K. T. K., Shanthakumar, G., Yenagi, N. \& Dutta, M. (2009). Food Security and Climate Change: Role of Plant Genetic Resources of Minor Millets. Indian. Journal of Plant Genetic. Resources. 22 (1): 1-16.

34. Pierreux, J. \& Bodson, B. (2013). La culture en association de blé et de pois d'hiver: une sécurité et une optimisation de la production de protéines en climat tempéré. Rencontre francophone légumineuses, 17-18 octobre 2018, Toulouse (France), 9p.

35. Platel, K., Eipeson, S.W. \& Srinivasan, K. (2010). Bioaccessible mineral content of malted finger millet (Eleusine coracana), wheat (Triticum aestivum), and barley (Hordeum vulgare). Journal of Agricultural and Food Chemistry, 58: 8100-8103.

36. ReSAKSS (2011). Regional Strategic Analysis and Knowledge Support System. Etude sur la consommation alimentaire en Afrique de l'Ouest, rapport de synthèse, $77 \mathrm{p}$.

37. Saleh, A. S.M., Zhang, Q., Chen, J., \& Shen, Q. (2013). Millet Grains: Nutritional Quality, Processing, and Potential Health Benefits. Journal of Food Science and Food Safety, 12: 281-295.

38. Singleton, V. L., Orthofer, R. \& Lamuela-Raventos, R. M. (1999). Analysis of total phenols and other oxidant substrates and antioxidants by means of Folin-Ciocalteu reagent. Methods Enzymology, 299: 152178.

39. Shahidi, F. \& Chandrasekara, A. (2013). Millet grain phenolics and their role in disease risk reduction and health promotion: a review. Journal of Functional Foods, 5: 570-581.

40. Shobana, S., Harsha, M. R., Platel, K., Simwemba, C. G., Hoseney, R. C. Varriano-Marston, E. \& Zeleznak, K. (2010). Some vitamin B and 
phytic acid contents of pearl millet (Pennisetum americanum (1.) Leeke). Journal of Agricultural and Food Chemistry 32: 41-48.

41. Smith, P., Sones, K., Grace, D., MacMillan, S., Tarawali, S. \& Herrero, M. (2013). Beyond milk, meat and eggs: role of livestock in food and nutrition security. Anim. Front, 3: 6-13.

42. Udeh, H.O., Duodu, K.G. \& Jideani, A. I. O. (2017). Finger millet bioactive compounds, bioaccessibility, and potential health effects a review. Czech. Journal of Food Sciences, 35: 7-17.

43. Van Soest, P. S. (1963). Use of detergents in analysis of fibrous feeds II-A rapid method for determination of fiber and lignin. A.O. A. C., 46: 829-835. 